\title{
Axial Bonds in Copper(II) Cyclam with DMF Ligands
}

\author{
Ju Chang Kim* and Alan J. Lough* \\ Department of Chemistry, Pukong National Chiversity. Pusan 608-737. Korea. ${ }^{*}$ E-mail: kimjciápknuackr \\ - Department of Chemistr. Chiversity of Tononto. Torono. ONT. Canada MSS $3 \mathrm{H} 6$ \\ Received August 11, 2004
}

Key Words : Copper(II) complex, Crystal structure. Cyclam

There have been many examples of copper(II) tetraazamacrocycles where the axial donors interact with copper(II) ions..$^{1-5}$ However the complexes reported usually show considerably long $\mathrm{Cu}$-axial donor distances with weak interactions between metal centers and axial donors. Even such weak interactions. it appears that the presence of hydrogen-bonding chelate rings comprised of axial donors. suitable anions and solvents. and secondary amines of the macrocycle is requisite for the stabilization of axial ligands to the central copper(II) ions. ${ }^{1-4}$ In the present work. we describe the preparation and structure of trans-[Cu(L)$\left.(\mathrm{DMF})_{2}\right]\left(\mathrm{PF}_{6}\right)_{2} \quad$ (1) $(\mathbf{L}=$ cyclam $=1.4 .8 .11$-tetraazacy clotetradecane. $\mathrm{DMF}=\mathrm{N} \cdot \mathrm{N}$-dimethylformamide), where the complex shows fairly strong copper-axial donor interactions without the support of hydrogen-bonding chelate rings.

\section{Experimental Section}

Materials, methods and apparatus. All chemicals used in this work were of reagent grade and were used without further purification. Infrared spectra were measured as Nujol mulls between $\mathrm{KBr}$ plates using a Perkin-Elmer Paragon 1000 FT-IR spectrophotometer over the range 4000 and 400 $\mathrm{cm}^{-1}$. Solid state electronic spectra by the diffuse reflectance method were measured using Shimadzu 2401-PC UV/vis spectrophotometer. The complex $[\mathrm{Cu}(\mathbf{L})]\left(\mathrm{ClO}_{4}\right)_{2}$ was prepared according to the literature procedures. ${ }^{6}$

trans-[Cu(L)(DMF) $\left.)_{2}\right]\left(\mathrm{PF}_{6}\right)_{2}$ (1). Excess amount of $\mathrm{NH}_{4} \mathrm{PF}_{6}$ was added to a warm acetonitrile $(20 \mathrm{~mL})$ solution of $[\mathrm{Cu}(\mathrm{L})]\left(\mathrm{ClO}_{4}\right)=(0.3 \mathrm{~g})$, then the complex was dissolved and white $\mathrm{NH}_{4} \mathrm{ClO}_{4}$ was precipitated. After the solids were removed by filtration. water was added to the filtrate until the purple crystals formed. $[\mathrm{Cu}(\mathbf{L})]\left(\mathrm{PF}_{6}\right) \leq$ was dissolved in a minimum amount of $\mathrm{DMF} / \mathrm{H}_{3} \mathrm{O}$. which was allowed in an open beaker at room temperature. After several weeks. the target complex 1 was separated out as purple plates just before the solution was dried up. Suitable crystals of $\mathbf{1}$ for $\mathrm{X}$-ray diffraction studies and subsequent spectroscopic measurements were manually collected under the microscope. Anal. Calcd. for $\mathrm{C}_{16} \mathrm{H}_{38} \mathrm{CuF}_{12} \mathrm{~N}_{6} \mathrm{O}_{2} \mathrm{P}_{2}$ (1): C. 27.43: $\mathrm{H}$. 5.43: N. 12.00. Found C. 27.42: H. 5.42: N. $12.41 \%$. IR (Nujol $\left.\mathrm{cm}^{-1}\right): 3279(\mathrm{lNH}), 1650(\mathrm{VCO})$.

X-ray crystallography. A summary of selected crystallographic data and selected interatomic distances and angles for 1 are given in Tables 1 and 2. X-ray data were collected on a Nonius Kappa CCD diffractometer. using graphite monochromated Mo K $\alpha$ radiation $(\lambda=0.71073$ A). A combination of $1^{\circ}$ phi and omega (with kappa offsets) scans were used to collect sufficient data. The data frames were integrated and scaled using the Denzo-SMN package. ${ }^{7}$ The structure was solved and refined. using the SHELXTL $\backslash P C$ V5.1 package. ${ }^{8}$ Refinement was performed by full-matrix least squares on $\mathrm{F}^{2}$ using all data (negative intensities included). Hy'drogen atoms were included in calculated positions. except for those involving hydrogen bonding specifically for the hydrogen atoms bonded to the nitrogen atoms. which were refined with isotropic thermal parameters.

\section{Results and Discussion}

Upon recrystallization of $[\mathrm{Cu}(\mathbf{L})]\left(\mathrm{PF}_{6}\right)$, from $\mathrm{DMF} / \mathrm{H}_{2} \mathrm{O}$. we obtained the DMF coordinated complex 1 as purple plates. The crystals of 1 retain their transparency for several weeks in a refrigerator. but they slowly decompose upon exposure to the atmosphere as evidenced by elemental analysis. The infrared spectrum and microanalysis for 1 clearly support the structure determined by the X-ray diffraction studies as described in the Experimental Section

The crystal structure of 1 consists of a monomeric $\left[\mathrm{Cu}(\mathbf{L})(\mathrm{DMF})_{2}\right]^{2-}$ cation and $\mathrm{PF}_{6}$ anions (Figure 1). The

Table 1. Crystal data and structure refinement for 1

\begin{tabular}{|c|c|}
\hline Empirical fonmula & $\mathrm{C}_{15} \mathrm{H}_{38} \mathrm{CuF}_{12} \mathrm{~N}_{5} \mathrm{O}_{2} \mathrm{P}_{2}$ \\
\hline Formula weight & 700 \\
\hline Temperature (K) & $150(1)$ \\
\hline Wavelength & $0.71073 \AA$ \\
\hline Crystal system & Monoclinic \\
\hline Space group & $\mathrm{C} 2 / \mathrm{c}$ \\
\hline \multirow[t]{4}{*}{ Unit cell dimensions } & $a=20.8877(5) \AA$ \\
\hline & $b=10.3326(3) A$ \\
\hline & $c=16.3753(3) \AA$ \\
\hline & $\beta=128.2320(10)^{\circ}$ \\
\hline Volume & $2776.14(12) \AA^{3}$ \\
\hline 2 & 4 \\
\hline Density (calculated) & $1.675 \mathrm{Mg} / \mathrm{m}^{3}$ \\
\hline Absorption coefficient & $1.010 \mathrm{~mm}^{-1}$ \\
\hline Independent reflections & $3158[\mathrm{R}(\mathrm{int})=0.0338]$ \\
\hline Goodness-of-fit on $\mathrm{F}^{2}$ & 1.050 \\
\hline Final R indices $[I>2 \sigma(I)]$ & $\mathrm{R} 1=0.0392, w \mathrm{R} 2=0.0948$ \\
\hline $\mathrm{R}$ indices (all data) & $\mathrm{R} 1=0.0558, w \mathrm{R} 2=0.1053$ \\
\hline
\end{tabular}


Table 2. Selected bond distances ( $\AA$ ) and angles (") for 1

\begin{tabular}{llll}
\hline $\mathrm{Cul-N1}$ & $2.0306(19)$ & $\mathrm{Cul}-\mathrm{N} 2$ & $2.0277(19)$ \\
$\mathrm{Cul-Ol}$ & $2.3985(17)$ & $\mathrm{Ol}-\mathrm{C} 6$ & $1.237(3)$ \\
$\mathrm{N} 3-\mathrm{C} 6$ & $1.323(3)$ & & \\
N2\#1-Cul-N1\#1 & $94.11(8)$ & N2-Cul-Nl\#1 & $85.89(8)$ \\
N2-Cul-Ol & $94.09(7)$ & N2-Cul-Ol\#1 & $85.91(7)$ \\
N1-Cul-Ol & $88.36(7)$ & Nl-Cul-Ol\#1 & $91.64(7)$ \\
\hline
\end{tabular}

Symmetry transtomations used to generate equivalent atoms: $1-\mathrm{x}-1$ $2,-\mathrm{y}-1 ; 2,-\mathrm{z}-1$

macrocyclic ligand skeleton of the complex 1 takes the most stable "trans III" conformation with two chair form six-membered and two gauche five-membered chelate rings. All inversion center exists on the central copper(II) ion. Two DMF molecules are coordinated to the central copper(II) ion in axial sites. The coordination environment around the central copper(II) ion shows a tetragonally distorted octahedron with four $\mathrm{Cu}-\mathrm{N}$ and two $\mathrm{Cu}-\mathrm{O}$ bonds. The four $\mathrm{Cu}-\mathrm{N}$ distances are in the range of $2.0306(19)-2.0277(19) \AA$. The $\mathrm{Cu}-\mathrm{O}$ distance of 2.3985 (17) $A$ is considerably shorter than those found in related systems $\left(\left[\mathrm{Cu}(\mathbf{L})\left(\mathrm{H}_{2} \mathrm{O}\right)=\right] \mathrm{F}_{2}+\mathrm{H}_{2} \mathrm{O}^{2} \quad \mathrm{Cu}-\mathrm{O}=2.484(6) \quad \AA\right.$ : $\left(\left[\mathrm{Cu}(\mathrm{en})_{2}\left(\mathrm{H}_{2} \mathrm{O}\right)_{2}\right] \mathrm{F}_{2} \cdot 4 \mathrm{H}_{2} \mathrm{O}^{2} \mathrm{Cu}-\mathrm{O}=2.571\right.$ (6) $\mathrm{A}$. en $=$ ethy lenediamine: $\left(\left[\mathrm{Cu}(\mathrm{L1})\left(\mathrm{H}_{2} \mathrm{O}\right)_{2}\right] \mathrm{Cl}_{2}{ }^{+} \mathrm{Cu}-\mathrm{O}=2.649(2)\right.$ A. $\mathbf{L 1}=3,14$-dimethyl-2.6,13,17-tetraazatricyclo[14,4.0 $0^{1.18}$. $\left.0^{7.13}\right]$ docosane: $\left(\left[\mathrm{Cu}(\mathrm{L} 2)\left(\mathrm{H}_{2} \mathrm{O}\right)_{2}\right] \mathrm{Cl}_{2}{ }^{3} \mathrm{Cu}-\mathrm{O}=2.666(2) \AA\right.$. L2 = 3,5,10.12-tetrantethyl-1.4.8.11-tetraazacyclotetradecane: $\left(\left[\mathrm{Cu}(\mathrm{L})\left(\mathrm{CH}_{3} \mathrm{CN}\right)_{2}\right]\left(\mathrm{CF}_{3} \mathrm{SO}_{3}\right)_{2}: 9 \mathrm{Cu}-\mathrm{N}_{\text {caial }}=2.570(5) \AA\right.$ $\left(\left[\mathrm{Cu}(\mathrm{L1})\left(\mathrm{CH}_{3} \mathrm{CN}\right)_{2}\right]\left(\mathrm{PF}_{6}\right)_{2}{ }^{5} \mathrm{Cu}-\mathrm{N}_{\text {axial }}=2.594(2) \mathrm{A}\right)$. One of the salient structural features found in 1 is the shortness of $\mathrm{Cu}-\mathrm{O}$ distances. Although no hydrogen-bonding chelate rings are involved in 1, the DMF molecules. which form stronger coordination than water molecules, preferentially coordinate to the copper(II) ion in $\mathrm{DMF} / \mathrm{H}_{2} \mathrm{O}$ cosolvents. The $\mathrm{PF}_{6}$ anions mediate between the two $\left[\mathrm{Cu}(\mathrm{L})(\mathrm{DMF})_{2}\right]^{\hat{2}^{+}}$ units through hydrogen bonding interactions $(\mathrm{N}(\mathrm{l})-\mathrm{H}(\mathrm{l}) \cdots$ $\mathrm{F}(2)=3.305(3) \mathrm{A} .(\mathrm{N}(1)-\mathrm{H}(1) \cdots \mathrm{F}(3)=3.197(3) \AA .(\mathrm{N}(2)-$ $\mathrm{H}(2) \cdots \mathrm{F}(4) \# 2=3.181(3) \mathrm{A}, \# 2 \mathrm{x}+1 / 2, \mathrm{y}+1 / 2,-\mathrm{z}+3 / 2)$.

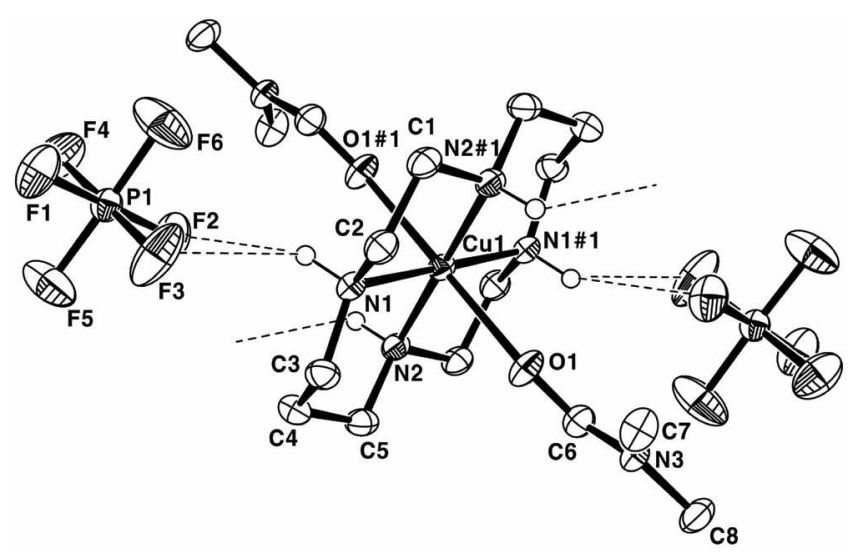

Figure 1. Molecular structure of 1 with atom-labeling scheme. Hydrogen atoms other than those participating in hydrogen bonding are omitted for clarity. resulting in the formation of hydrogen bonded polymer. The presence of $\mathrm{PF}_{\mathrm{i}}$ as anions appears to be crucial for the formation of DMF coordinated complex 1. It was unsuccessful to obtain such a complex by using $[\mathrm{Cu}(\mathrm{L})]\left(\mathrm{ClO}_{4}\right)_{2}$ instead of $[\mathrm{Cu}(\mathrm{L})]\left(\mathrm{PF}_{6}\right)_{2}$. In the 14-membered copper(II) tetraazamacrocyclic systems, it has been generally recognized that the axial bonds are achieved when the hydrogen bonds play a role in stabilizing the coordination of an appropriate donor ligands to the central metal ions. ${ }^{3-4}$ One of the exceptions is the interaction of $\mathrm{CH}_{3} \mathrm{CN}$ to the copper(II) ion ${ }^{59}$ This is possibly due to the fairly good $\sigma$ donor and $\pi$-acceptor properties of $\mathrm{CH}_{3} \mathrm{CN}$. In the present complex 1, the DMF molecule shows even stronger interactions to the copper(II) ion than $\mathrm{CH}_{3} \mathrm{CN}$ ([Cu(L)(DMF) $]-$ $\left(\mathrm{PF}_{6}\right)_{2} . \mathrm{Cu}-\mathrm{O}=2.3985(17) \AA ;\left(\left[\mathrm{Cu}(\mathrm{L1})\left(\mathrm{CH}_{3} \mathrm{CN}\right)_{2}\right]\left(\mathrm{PF}_{6}\right)_{2} \cdot{ }^{5}\right.$ $\mathrm{Cu}-\mathrm{N}_{\alpha \rightarrow a l}=2.594(2) \AA:\left[\mathrm{Cu}(\mathbf{L})\left(\mathrm{CH}_{3} \mathrm{CN}\right)_{2}\right]\left(\mathrm{CF}_{3} \mathrm{SO}_{3}\right)_{2} \cdot{ }^{11} \mathrm{Cu}-$ $\mathrm{N}_{a x i a l}=2.570(5) \AA$ ). For DMF ligands coordinated through oxygen. internal bond distances of $\mathrm{C}-\mathrm{O}=1.237(3) \mathrm{A}$ and $\mathrm{C}$ $\mathrm{N}=1.323(3) \AA$ lengthen compared to those of the lattice DMF $(\mathrm{C}-\mathrm{O}=1.221(7) \AA, \mathrm{C} \cdot \mathrm{N}=1.315(7) \AA){ }^{10}$ This is in accord with the band assigned as carbonyl stretch in the IR spectrum showing $-20 \mathrm{~cm}^{-1}$ to lower energies for 1 ( $\mathrm{lCO}=$ $\left.1650 \mathrm{~cm}^{-1}\right)$ compared to that of neat DMF $(\mathrm{LCO}=1670$ $\mathrm{cm}^{-1}$ ). The solid state electronic spectrum in the visible region shows a band at $543 \mathrm{~nm}$ which represents a

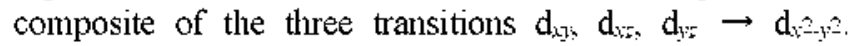
However. the lowest energy absorption due to the $d_{z} \rightarrow$ $\mathrm{d}_{x-1} \geq$ transition was not observed in 1. In general. the electronic spectra of octahedral copper(II) complexes exhibit a characteristic two-band pattem due to the Jalun-Teller induced tetragonal distortions." On this account. the complex 1 containing two DMF ligands could be a good system for the understanding of probable copper(II) catalyzed hydrolysis of DMF. The behavior of the complex 1 in solvents of varying $\mathrm{pH}$ is currently under investigation.

Supplementary material. Crystallographic data have been deposited at the Cambridge Crystallographic Data Center (CCDC), CCDC No. 246464 for 1 .

\section{References}

1. Kang. S.G.: Kim. S.-T.: Teong. J. H. Polwhedron 1998. 17. 3227.

2. Choi. K.-Y: Kim. T. C. Jensen. W. P.: Suh. I.-H.: Choi. S.-S. Acta Crystallogr 1996. C52.2166.

3. Choi. K.-Y.: Sul, I.-H.; Kim. J. C. Bull Korean Chem. Soc. 1997. 18. 1321.

4. Kim. J. C.: Lough. A. J. Tronsition Het. Chem 2003. $28,300$.

5. Kiml. J. C.: Fettinger. J. C.: Kiml. Y. I. Horg. Chin. Acta 1999. 286.67.

6. Tasker. P. A.: Sklar. L. Chst. Mol. Struct 1975. 5. 329.

7. Otwinowski, Z.: Minor, W. Hethods Enzymol 1997. 276, 1783

8. Sheldrick, G. M. SHELIZiPC V5.1; Bruker Analytical X-ray Systems: Madison. WI. 1997.

9. Scott. M. T.: Holm. R. H. J. Am. Chent Soc. 1994. 116. 11357.

10. Hunt. G. W: Griffith. E. A. H.: Amma. E. L. Ihorg. Chem. 1976. 15. 2993.

11. Donlevy, I: M: Gahan. L. R: Hambley. I: W: Hanson. G. R.: MeMahon. K. L. Stranger. R. Horg. Chem. 1994. 33. 5131 . 